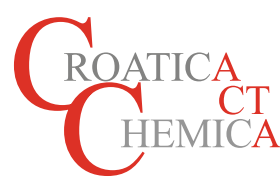

\title{
UV-Vis and ESI MS/MS Study of Calix[4]arene Derivatives and Their Lanthanide Complexes
}

\author{
Marina Tranfić Bakić, ${ }^{1}$ Mariela Soledad Espinosa, ${ }^{2}$ Nikola Cindro, ${ }^{3}$ Leo Frkanec, ${ }^{4}$ Paola Alejandra Babay, ${ }^{2}$ Nives Galić ${ }^{3, *}$
}

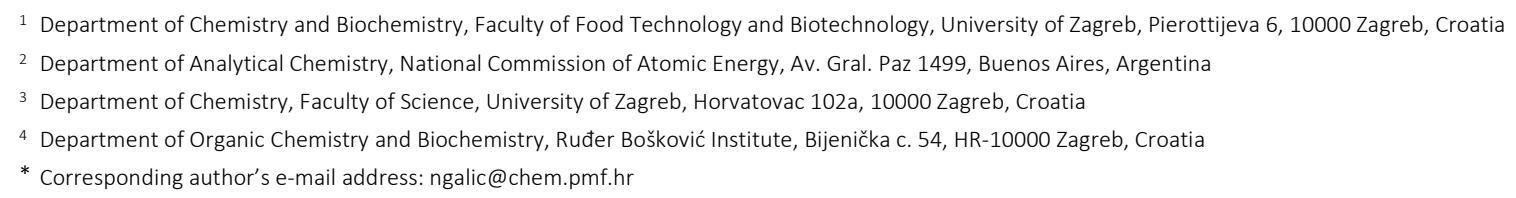

RECEIVED: January 19, 2018 * REVISED: April 9, 2018 * ACCEPTED: April 12, 2018

THIS PAPER IS DEDICATED TO PROF. MLADEN ŽINIĆ ON THE OCCASION OF HIS 70 ${ }^{\mathrm{TH}}$ BIRTHDAY

\begin{abstract}
Coordination properties of calix[4]arenes bearing substituents on the lower rim: tetraethyl ester (1), tetraethylamide (2), and newly synthesized tetraethylmethylamide derivative (3), towards selected lanthanide cations $\left(\mathrm{La}^{3+}, \mathrm{Eu}^{3+}, \mathrm{Yb}^{3+}\right.$ ) were studied by spectrophotometric titrations. No complexation was observed with ester derivative, while amide derivatives formed 1:1 complexes and bound lanthanide cations very efficiently ( $\lg K_{\mathrm{La2}}=5.1 ; \lg K_{\mathrm{Eu2}} \geq 6$; $\lg K_{\mathrm{rb} 2} \geq 6$; $\lg K_{\mathrm{Laz}} \geq 6$; $\lg K_{\mathrm{Eu}} \geq 6 ; \lg K_{\mathrm{rb}_{3}} \geq 6$ ). The ligands and complexes were also analysed by ESI MS and MS/MS spectrometry. Both inductive cleavage and proton rearrangement fragmentation reactions were observed. Corresponding fragmentation pathways were proposed. The results obtained by MS analysis were in accordance with those obtained by spectrophotometric titrations.
\end{abstract}

Keywords: calixarenes, lanthanides, electrospray mass spectrometry, UV-Vis spectroscopy.

\section{INTRODUCTION}

$\mathrm{N}$ the management of nuclear waste, the intra- and inter

group separation of lanthanides (Ln) and actinides (An) families of elements plays an important role. ${ }^{[1]}$ Treatment and reprocessing of acidic nuclear waste arising from the generation of nuclear energy still remains one of the most crucial problems. Actinides, long-lived radionuclides, are among the most hazardous components of high level liquid waste (HLLW). Their recovery should significantly enhance the environmental safety and the efficiency of the nuclear fuel cycle. ${ }^{[2]}$ The separation of An from $\operatorname{Ln}$ is an essential task to establish the transmutation technology (transformation of a large fraction of the long term source of radioactivity, radiotoxicity and heat, like the minor actinides $\mathrm{Am}$ and $\mathrm{Cm}$ and long lived fission fragments, into stable or short lived materials).[3] The presence of lanthanides, which account for almost one third of the fission products and are strong neutron-absorbing elements, will prevent the efficient transmutation of Am and $\mathrm{Cm}$ from HLLW. Such separation, however, is a key challenge due to the very similar chemical behavior of the two elements families. ${ }^{[1-3]}$

Some decades ago, in CEA (Commissariat à l'énergie atomique et aux énergies alternatives, France) the idea of using calixarenes for the selective extraction of radionuclides like ${ }^{99} \mathrm{Tc}$ and ${ }^{135} \mathrm{Cs}$ from HLLW was introduced. ${ }^{[1,4,5]}$ Since then, significant attention has been paid on supramolecular ligands based on calixarene platforms in investigations oriented towards nuclear waste treatment. ${ }^{[1,2]}$ Calixarenes have in general high melting points, high chemical and thermal stability, low solubility and low toxicity. ${ }^{[1]}$ As macrocyclic extractants, they offer the possibility to recognize cations selectively. Calixarenes of different ring sizes can combine with hydrophobic as well as ionophilic groups, thus allowing selective inclusion and extraction of cations, ranging from alkaline and alkaline earth to heavy metal ions. ${ }^{[6]}$ The lower rim phenolic hydroxyls can be functionalized to provide a variety of donor groups by relatively straightforward reactions. $[2,6,7]$

(c) B. BY This work is licensed under a Creative Commons Attribution 4.0 International License. 
Calixarenes functionalized with carbamoyl phosphine oxide (CMPO) groups proved to be good extractants for separation of lanthanides and actinides in the frame of nuclear reprocessing research. Matulkova and Rohovec ${ }^{[8]}$ synthesized calix[4]arenes with four phosphonic acid groups on the lower rim and characterized their extraction behavior for $\mathrm{La}^{3+}, \mathrm{Eu}^{3+}$ and $\mathrm{Yb}^{3+}$, observing that the extraction efficiencies declined with decreasing radius of the lanthanide ions. Lamourux et al. ${ }^{[9]}$ studied the speciation of two calixarene-CMPO derivatives, substituted either in the lower or the upper rim, with $\mathrm{La}^{3+}, \mathrm{Eu}^{3+}, \mathrm{Yb}^{3+}$. They reported the stoichiometries of the complexes and determined the selectivity of these calixarenes towards lanthanides. Yaftian et al. ${ }^{[10]}$ studied the extraction of $\mathrm{Th}^{4+}$ and $\mathrm{Eu}^{3+}$ by a phosphorylated calix[4]arene in dichloromethane and investigated the effects of ligand concentration, types of diluent and concentration of the salting out agents. Karavan et al. ${ }^{[11]}$ used three series of phosphorylated calixarene derivatives bearing phosphine oxide or phosphonate groups, either at the upper or the lower rims for recognition and extraction of europium, americium, thorium and uranyl ions.

On the other hand, introduction of functional groups containing nitrogen atoms such as amides to the calixarene molecule, should enhance its coordination ability towards transition and inner transition metal cations. These derivatives are interesting alternatives, in the search of an ideal extractant to be used in nuclear waste partitioning. Due to the presence of phosphorus atoms in their molecules, CMPO cannot be completely burned. To be incinerated to a gaseous product after utilization and not giving rise to the increase of secondary solid waste, the ideal extractant should only consist of $\mathrm{C}, \mathrm{H}, \mathrm{O}$, and $\mathrm{N}$ atoms. ${ }^{[3]}$ Mariani et al. ${ }^{[12]}$ investigated calixarene-based picolinamide ligands, determined the distribution coefficients for actinides and lanthanides and used them for liquid-liquid extraction of ${ }^{241} \mathrm{Am}$ and ${ }^{152} \mathrm{Eu}$ in high radioactive nitric solutions before and after irradiation. Wang et al. ${ }^{[13]}$ reported a piperidine-modified calix[4] arene derivative with enhanced recognition of rare earth metals. Diglycolamides were found to be promising ligands for acidic waste partitioning. ${ }^{[14]}$ Huang et al. ${ }^{[3]}$ syntethized a calix[4]arene appended with four diglycolamide moieties containing $n$-butyl groups and studied its extraction behavior for $\mathrm{Am}^{3+}$ and $\mathrm{Eu}^{3+}$ from nitric acid solution.

Previously, we have reported the results of spectrometric studies on binding properties of some peptidocalixarenes towards alkali-metal and selected lanthanide cations $\left(\mathrm{La}^{3+}, \mathrm{Ce}^{3+}, \mathrm{Eu}^{3+}, \mathrm{Yb}^{3+}\right) .{ }^{[15]}$ In this work, we present UV-Vis spectroscopic and mass spectrometric investigations of ester and amide derivatives of calix[4]arenes, namely 5,11,17,23-tetra-tert-butyl-25,26,27,28-tetrakis-[(ethoxycarbonyl)methoxy]-calix[4]arene (1), 5,11,17,23- tetra-tertbutyl-25,26,27,28-tetrakis( $N$-ethyl-carbamoylmethoxy)calix[4]arene (2), 5,11,17,23-tetra-tert-butyl-25,26,27,28tetrakis( $N$-ethyl- $N$-methyl-carbamoylmethoxy)calix[4]arene

(3) (Scheme 1) and their coordination properties towards selected lanthanides $\left(\mathrm{La}^{3+}, \mathrm{Eu}^{3+}, \mathrm{Yb}^{3+}\right)$.

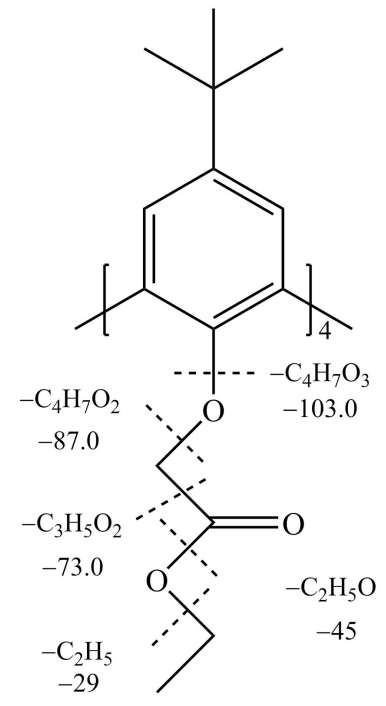

$1\left(\mathrm{C}_{60} \mathrm{H}_{80} \mathrm{O}_{12}, 992.56\right)$

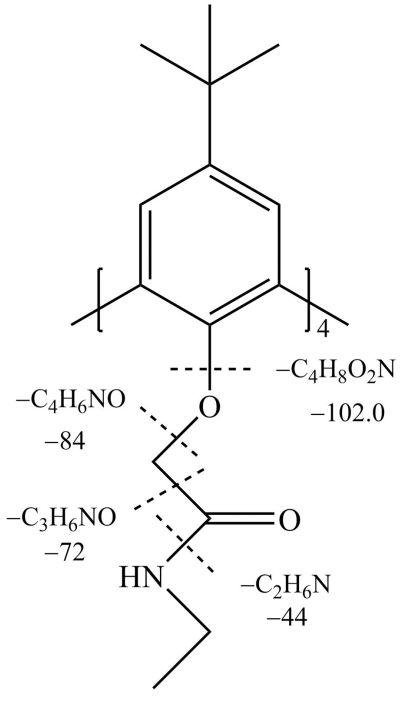

$2\left(\mathrm{C}_{60} \mathrm{H}_{84} \mathrm{~N}_{4} \mathrm{O}_{8}, 988.563\right)$

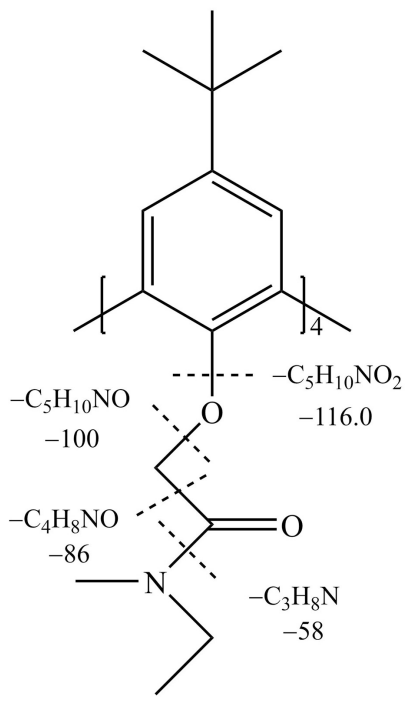

$3\left(\mathrm{C}_{64} \mathrm{H}_{92} \mathrm{~N}_{4} \mathrm{O}_{8}, 1044.69\right)$

Scheme 1. 


\section{EXPERIMENTAL}

\section{Materials}

The compounds $\mathbf{1}$ and $\mathbf{2}$ were synthesized according to the published procedures. ${ }^{[16,17]}$ The compound $\mathbf{3}$ was prepared as follows: calix[4]arene tetraacetic acid, the cone conformer prepared according to the previously described procedure, ${ }^{[18]}$ (1.00 g, $1.13 \mathrm{mmol}$ ) and thionyl chloride $(5.0$ $\mathrm{mL}$ ) were refluxed for one hour. Mixture was evaporated and then co-evaporated with dry toluene. Resulting acylchloride was redissolved in $50 \mathrm{~mL}$ of dry dichloromethane (DCM) and cooled under argon to $0{ }^{\circ} \mathrm{C}$. With vigorous stirring mixture of dry pyridine $(1.00 \mathrm{~mL}, 12.9 \mathrm{mmol})$ and $\mathrm{N}$-ethylmethylamine $(1.0 \mathrm{~mL}, 11.6 \mathrm{mmol}$ ) dissolved in 10 $\mathrm{mL}$ of dry DCM was added dropwise. Mixture was stirred under argon for 24 hours, diluted with DCM, washed 5 times with miliQ water and evaporated without drying. Crude compound was triturated with $20 \mathrm{~mL}$ of boiling acetonitrile and left to cool in refrigerator. Product was filtered and recrystallized from boiling ethanol, yielding 360 mg (31 \%) of pure compound. The ${ }^{1} \mathrm{H}$ and ${ }^{13} \mathrm{C}$ NMR spectra are given in Supporting information, FigureS1 and S2.

${ }^{1} \mathrm{H} \mathrm{NMR}\left(\mathrm{CDCl}_{3} / 400 \mathrm{MHz}\right) \delta / \mathrm{ppm}$ 6.86-6.69 (m, $8 \mathrm{H}), 5.26-5.07(\mathrm{~m}, 4 \mathrm{H}), 5.06-4.88(\mathrm{~m}, 8 \mathrm{H}), 3.47-3.30(\mathrm{~m}$, $8 \mathrm{H}), 3.18(\mathrm{~d}, 4 \mathrm{H}, \mathrm{J}=13.6 \mathrm{~Hz}), 3.00-2.86(\mathrm{~m}, 12 \mathrm{H}), 1.17-1.03$ $(\mathrm{m}, 36 \mathrm{H})$

${ }^{13} \mathrm{C} \mathrm{NMR}\left(\mathrm{CDCl}_{3} / 100 \mathrm{MHz}\right) \delta / \mathrm{ppm} 169.62$ (s), $153.99(\mathrm{~s}), 144.41(\mathrm{~s}), 133.59(\mathrm{~s}), 125.69(\mathrm{~d}), 72.04(\mathrm{t}), 43.43$ $(\mathrm{t}), 42.23(\mathrm{t}), 33.77(\mathrm{t}), 33.52(\mathrm{q}), 32.49(\mathrm{q}), 31.61(\mathrm{q}), 13.57$ (q), 12.32 (q). HRMS calculated for $\left(\mathrm{C}_{16} \mathrm{H}_{23} \mathrm{O}_{2} \mathrm{~N}\right)_{4}[\mathrm{M}+\mathrm{H}]^{+}$ 1045.6993 found 1045.6986 .

The salts used for complexation reactions were $\mathrm{La}\left(\mathrm{NO}_{3}\right)_{3} \times 6 \mathrm{H}_{2} \mathrm{O}, \mathrm{Eu}\left(\mathrm{NO}_{3}\right)_{3} \times 6 \mathrm{H}_{2} \mathrm{O}, \mathrm{Eu}\left(\mathrm{CF}_{3} \mathrm{SO}_{3}\right)_{3} 98 \%$, $\mathrm{Yb}\left(\mathrm{NO}_{3}\right)_{3} \times x \mathrm{H}_{2} \mathrm{O}$, (Fluka, p.a. and Sigma Aldrich, 99.99). The solvent, acetonitrile (Merck, Uvasol) was used without further purification.

\section{Spectrophotometry and Spectrofluorimetry}

UV titrations were performed using a Perkin-Elmer Lambda 25 double-beam spectrophotometer, whereas fluorimetric measurements were carried out using a PekinElmer LS-55 spectrofluorimeter, both equipped with a thermostating device. UV and fluorescence spectra were obtained at (25.0 $\pm 0.1){ }^{\circ} \mathrm{C}$ using quartz cells with $1 \mathrm{~cm}$ optical path length. Spectral changes of solutions of ligands were recorded upon stepwise additions of lanthanide salt solution directly into the measuring cell. Absorbances were collected with integration time of $0.2 \mathrm{~s}$, whereas fluorescence intensities were sampled with scanning speed of $600 \mathrm{~nm} \mathrm{~min}{ }^{-1}$, both with resolution of $0.5 \mathrm{~nm}$. Titrations for each $\mathrm{M}^{3+} / \mathrm{L}$ system $\left(\mathrm{M}^{3+}\right.$ stands for a lanthanide cation and $\mathrm{L}$ denotes a calix[4]arene ligand) were done at least in triplicate. The obtained data were processed using the HYPERQUAD program ${ }^{[19]}$ and OriginPro 2016. In the course of complexation considerations and determinations of stability constants, while ion-association was not taken into account, absorption of a nitrate anion was considered.

\section{Mass Spectrometry}

Ligand solutions $\left(c=1 \times 10^{-5} \mathrm{~mol} \mathrm{dm}^{-3}\right)$, as well as solutions with metal:ligand molar ratio $1: 1$ and $1: 10$ were prepared in acetonitrile. The ESI mass spectra of solutions were obtained on Agilent 6410 Triple Quadrupole Mass Spectrometer. Mass spectra were recorded in the range of $\mathrm{m} / \mathrm{z}=$ 10 to $\mathrm{m} / \mathrm{z}=2000$ in positive ion mode. Samples were introduced into mass spectrometer directly via Agilent 1260 HPLC (Agilent Technologies, Palo Alto, CA, USA). The mobile phase used was $50 \%$ acetonitrile (HPLC grade, J. T. Baker) in milli-Q water. The flow rate was $0.2 \mathrm{~mL} / \mathrm{min}$, and injection volume $5 \mu \mathrm{L}$. Capillary potential in mass spectrometer was $3.5 \mathrm{kV}$ and fragmentor voltage was 135 V. Gas temperature was $300{ }^{\circ} \mathrm{C}$ and gas flow rate was 8 $\mathrm{L} / \mathrm{min}$. Tandem mass spectrometry was performed with collision energies of $10 \mathrm{eV}$ up to $50 \mathrm{eV}$.

\section{RESULTS AND DISCUSSION}

\section{Spectrophotometric Titrations and Spectrofluorimetry}

To determine validity of Beer law the UV spectra of compounds 1-3 were acquired in acetonitrile (Figures S3S5) and optimal ligand concentrations for spectrophotometric titrations were determined. Upon stepwise additions of $\mathrm{La}\left(\mathrm{NO}_{3}\right)_{3}, \mathrm{Eu}\left(\mathrm{NO}_{3}\right)_{3}$, and $\mathrm{Yb}\left(\mathrm{NO}_{3}\right)_{3}$ salt solution into the acetonitrile solution of compound 1 , the increase of absorbance was recorded (Figures S6-S8). However, the increase was caused by the absorption of nitrate ion in this spectral region. That was confirmed by titration of 1 with acetonitrile solution of $\mathrm{Eu}\left(\mathrm{CF}_{3} \mathrm{SO}_{3}\right)_{3}$ in which no change in UV spectra was observed (Figure S9) suggesting that no complexation of lanthanide ions with ester calix[4]derivative took place.

Contrary to ester derivative, the amide derivatives have shown remarkable coordination properties towards lanthanide cations. The spectrophotometric titrations of compounds $\mathbf{2}$ and $\mathbf{3}$ with La ${ }^{3+}$ are shown in Figures 1 and 2 as well as titrations with other lanthanides in Figures S10-S15.

As can be seen from Figure 1, even compound 2, in which circular intramolecular hydrogen-bonds are formed between hydrogen-bond acceptor (carbonyl group) and hydrogen-bond donor (-NH- group), efficiently binds lanthanum cation, although these intramolecular hydrogen bonds usually reduce ionophoric activity of such ligands. ${ }^{[20-22]}$ 

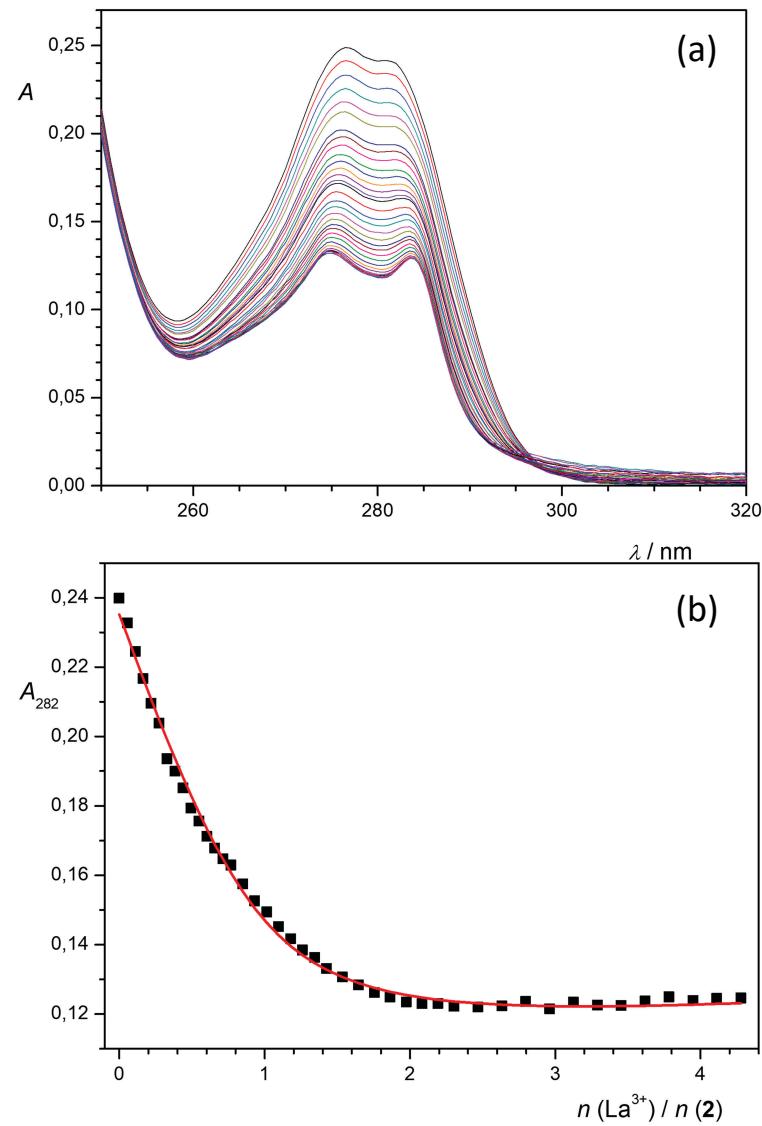

Figure 1. (a) Spectrophotometric titration of 2 ( $c=6.68 \times 10^{-5}$ $\left.\mathrm{mol} \mathrm{dm}{ }^{-3}\right)$ with $\mathrm{La}\left(\mathrm{NO}_{3}\right)_{3}$ in acetonitrile. $I=1 \mathrm{~cm} ; \vartheta=(25.0 \pm$ $0.1{ }^{\circ} \mathrm{C} ; c\left(\mathrm{La}^{3+}\right)=0$ (top curve) $-3.99 \times 10^{-4} \mathrm{~mol} \mathrm{dm}^{-3}$ (bottom curve); the spectra are corrected for dilution. (b) Dependence of absorbance at $276 \mathrm{~nm}$ on $\mathrm{La}^{3+}$ concentration. - experimental; — calculated.

Based on three titrations, the stability constant of $1: 1$ complex was determined, and amounted to: $\lg K_{\text {La2 }}=5.104$ \pm 0.008 . In all other titrations, a linear relationship of absorbance versus the amount of cation added was observed up to the ratio $n$ (cation) $/ n$ (ligand) $\approx 1$, followed by a break in the titration curve (Figures 2 and S10-S15). These findings revealed a formation of $1: 1$ complexes and rather strong complexation. Because of the limited sensitivity of spectrophotometry, stability constants for $\mathrm{Eu} \bullet \mathbf{2}^{3+}, \mathrm{Yb} \bullet 2^{3+}, \mathrm{La} \bullet \mathbf{3}^{3+}, \mathrm{Eu} \bullet \mathbf{3}^{3+}$, and $\mathrm{Yb} \bullet \mathbf{3}^{3+}$ complexes could be only estimated, $\lg K \geq 6$. It is well known that calix[4]derivatives bearing tertiary-amide groups at the lower rim have remarkably high affinities towards small alkali metal cations, like lithium and sodium. ${ }^{[23-25]}$ Since lanthanide cations have similar ionic radii to these ions (for coordination number 8: $\mathrm{Li}^{+}$92, $\mathrm{Na}^{+} 118, \mathrm{La}^{3+} 116, \mathrm{Eu}^{3+} 107$, and $\mathrm{Yb}^{3+} 98 \mathrm{pm}$ ) it is not surprising that compound $\mathbf{3}$ was precisely the most effective ligand among studied compounds.
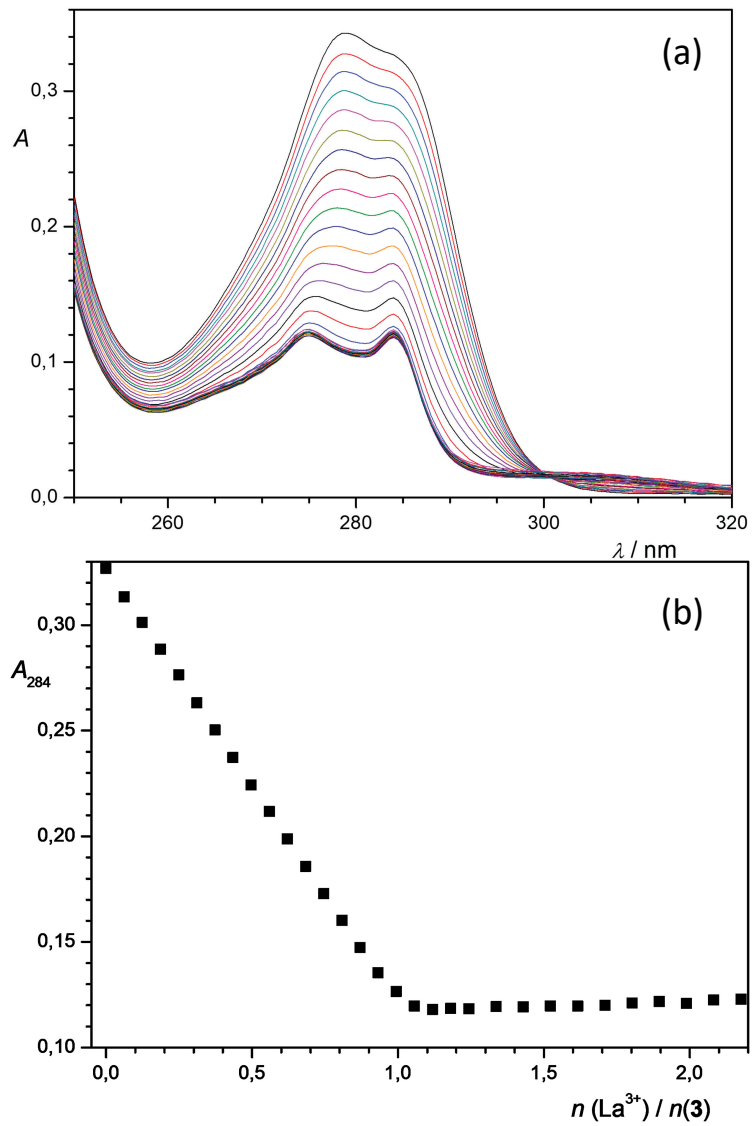

Figure 2. (a) Spectrophotometric titration of $3\left(c=6.42 \times 10^{-5}\right.$ mol dm$\left.{ }^{-3}\right)$ with $\mathrm{La}\left(\mathrm{NO}_{3}\right)_{3}$ in acetonitrile. $I=1 \mathrm{~cm} ; \vartheta=(25.0 \pm$ $0.1{ }^{\circ} \mathrm{C} ; \mathrm{C}\left(\mathrm{La}^{3+}\right)=0$ (top curve) $-3.99 \times 10^{-4} \mathrm{~mol} \mathrm{dm}^{-3}$ (bottom curve); the spectra are corrected for dilution. (b) Dependence of absorbance at $284 \mathrm{~nm}$ on $\mathrm{La}^{3+}$ concentration.

The emission spectra of the ligands and their complexes in acetonitrile were also recorded. The wavelength corresponding to absorption maxima (determined from the UV-Vis spectra) was used as excitation wavelength for spectrofluorimetric measurements. Unfortunately, free ligands did not show any significant fluorescence, and the changes upon addition of the cations were too small to provide any insight into the complexation process.

\section{Mass Spectrometry MS AND MS/MS SPECTRA OF COMPOUNDS 1-3}

The MS spectra of calixarene acetonitrile solutions (Figures 3 and S16-S17) were acquired in the mass range from 10 to $2000 \mathrm{~m} / \mathrm{z}$. Depending on a ligand, the most abundant ions were $[\mathrm{M}+\mathrm{H}]^{+}$or $[\mathrm{M}+\mathrm{Na}]^{+}$. The peaks corresponding to aducts with impurities already present in the system $\left(\mathrm{Na}^{+}\right.$, $\mathrm{K}^{+}, \mathrm{NH}_{4}{ }^{+}$) are usually observed in MS spectra of calixarene derivatives. ${ }^{9,15}$ 


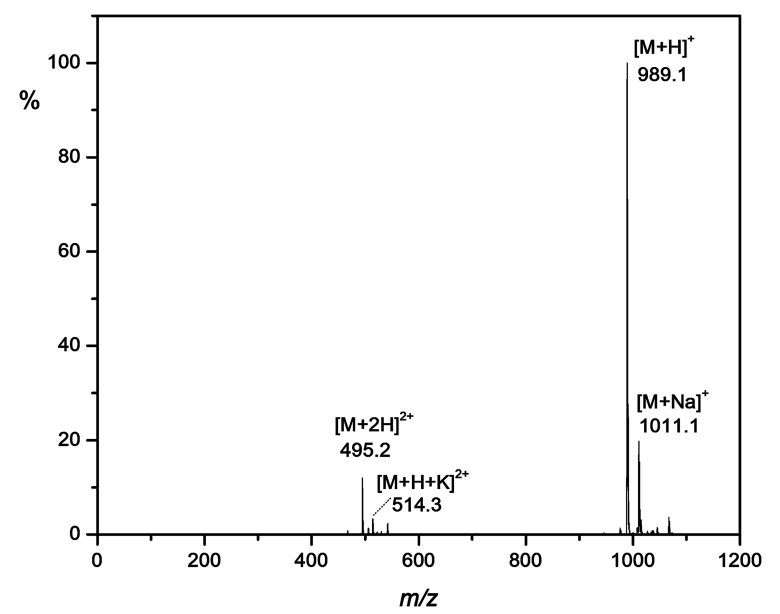

Figure 3. MS spectrum of $2\left(\mathrm{C}_{60} \mathrm{H}_{84} \mathrm{O}_{8} \mathrm{~N}_{4}\right.$, exact mass = 988.63) in acetonitrile. $c(2)=1 \cdot 10^{-3} \mathrm{~mol} \mathrm{dm}^{-3}$; fragmentor voltage $=135 \mathrm{~V}$.

MS/MS analyses of singly protonated molecular ions of calixarene derivatives 1-3 were performed at different collision energies, from 5 to $50 \mathrm{eV}$, and the fragmentation schemes were proposed. As an example, the MS/MS spectrum of 1 and corresponding fragmentation scheme are shown in Figure 4 and Scheme 2.

As can be seen, the combination of different cleavages was observed. By inductive cleavage of bond in vicinity of the carbonyl group and loss of fragment $-\mathrm{C}_{3} \mathrm{H}_{5} \mathrm{O}_{2}$, the ion $\mathrm{m} / \mathrm{z} 919$ was formed. The loss of $-\mathrm{C}_{2} \mathrm{H}_{5}$ group from one subunit, and loss of whole subunit by proton rearangement mechanism led to the ion $\mathrm{m} / \mathrm{z} 863$. However, the loss of one subunit, and the fragment $-\mathrm{C}_{2} \mathrm{H}_{5} \mathrm{O}$ by heterolytic cleavage let to the ion $\mathrm{m} / \mathrm{z} 845$. The ion $\mathrm{m} / \mathrm{z} 807$ was formed by the proton rearrangement mechanism and loss of fragments $-\mathrm{C}_{4} \mathrm{H}_{7} \mathrm{O}_{2},-\mathrm{C}_{3} \mathrm{H}_{5} \mathrm{O}_{2}$, and $-\mathrm{C}_{2} \mathrm{H}_{5}$ from three subunits. In the MS/MS spectrum acquired at $20 \mathrm{eV}$, the signals corresponding to one and two subunits at $\mathrm{m} / \mathrm{z} 263.0$ and 511.0, respectively were observed. By increasing the collision energy to $30 \mathrm{eV}$, the signal of precursor ion, $[\mathbf{1 + H}]^{+}$ almost completely diminished.

Compound $\mathbf{2}$ did not fragment at collision energies lower than $30 \mathrm{eV}$. By applying this amount of energy, the cleavage of bonds in $\alpha$ - and $\beta$ - position to heteroatom in subunits were observed (Scheme 3, Figure S18) leading to fragment ions $m / z 944$ and 916 . At higher collision energy, $40 \mathrm{eV}$ (Figure S19), the cleavage of calixarene ring occurred, which, however, differs from the fragmentation pattern of 1. Even when applying $50 \mathrm{eV}$ for collision, the signal in the $\mathrm{MS} / \mathrm{MS}$ spectrum assigned to $[\mathbf{2}+\mathrm{H}]^{+}$was still present indicating the stability of the molecular ion, probably due to the presence of intramolecular $\mathrm{H}$-bonds.

Compound 3, p-tert-butylcalix[4]arene tetraethylmethylamide fragmented in similar way. At lower collision

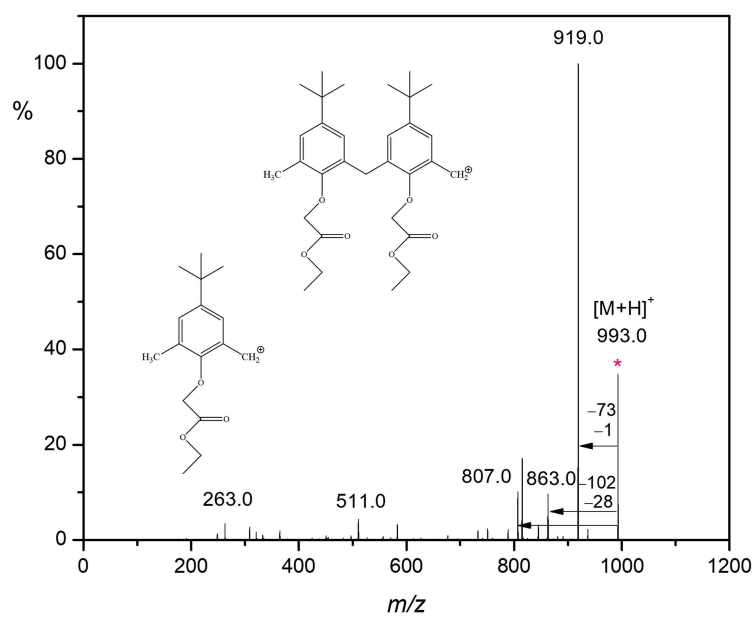

Figure 4. MS/MS spectrum of $[1+\mathrm{H}]^{+}(\mathrm{m} / \mathrm{z} 993)$ at $20 \mathrm{eV}$.

energies $(10,20$ and $30 \mathrm{eV})$ no fragmentation occurred indicating that amide derivatives are more stable in gas phase than the ester one. The MS/MS spectrum at $40 \mathrm{eV}$ is shown in Figure S20, and the proposed fragmentation pathway in Scheme 4. In addition to loss of part of subunits $\left(-\mathrm{C}_{4} \mathrm{H}_{8} \mathrm{NO}\right)$ and the whole subunit $\left(-\mathrm{C}_{5} \mathrm{H}_{10} \mathrm{NO}_{2}\right)$, the signals at $\mathrm{m} / \mathrm{z} 58$ and 72 , assigned to the small stable cyclic fragments of calixarene derivative, were observed in the spectrum.

\section{MS AND MS/MS SPECTRA OF LANTHANIDE COMPLEXES}

The full scan MS spectra of acetonitrile solutions of lanthanide calixarene complexes with molar ratios $n\left(\mathrm{Ln}^{3+}\right)$ : $n$ (ligand) $=1: 1$ or $10: 1$ were almost the same (Figure 5 , S21-S26). Slightly higher intensities of [ligand+Ln] $]^{3+}$ ions were observed in MS spectra of $1: 1$ solutions. Although the salt amount had insignificant influence of MS spectra, the difference in MS spectra were noticed with respect to anion used (Figure 5). In MS spectra of complexes with ligand 2 , the base signals were assigned to the ion $[2-87+L n]^{2+}$ which was formed by cleavage of amide bonds in two calixarene subunits, except in the MS spectrum of europium triflate complex, where the most intense signal was assigned to $\left[2+\mathrm{Eu}\left(\mathrm{CF}_{3} \mathrm{SO}_{3}\right)\right]^{2+}$ ion. $\mathrm{MS}$ spectra of complexes with $\mathbf{3}$ were more intricate, and the most intensive signals were the ones assigned to $\left[3+\operatorname{Ln}\left(\mathrm{NO}_{3}\right)\right]^{2+}$ ions.

No complexation reactions with ester derivative were observed, which was in accordance with the results of UV titrations. In the continuation of the work, the comprehensive MS/MS analyses were performed on all singly and multiply charged ions noticed in the MS spectra of lanthanide complexes.

$\mathrm{MS} / \mathrm{MS}$ spectra of triply charged ions were recorded at 5 and $7 \mathrm{eV}$ (Figure 6, Figures S27-S28). By applying $5 \mathrm{eV}$ no difference in the fragmentation of the complexes with 2 was observed, only the cleavage of two ether bonds 


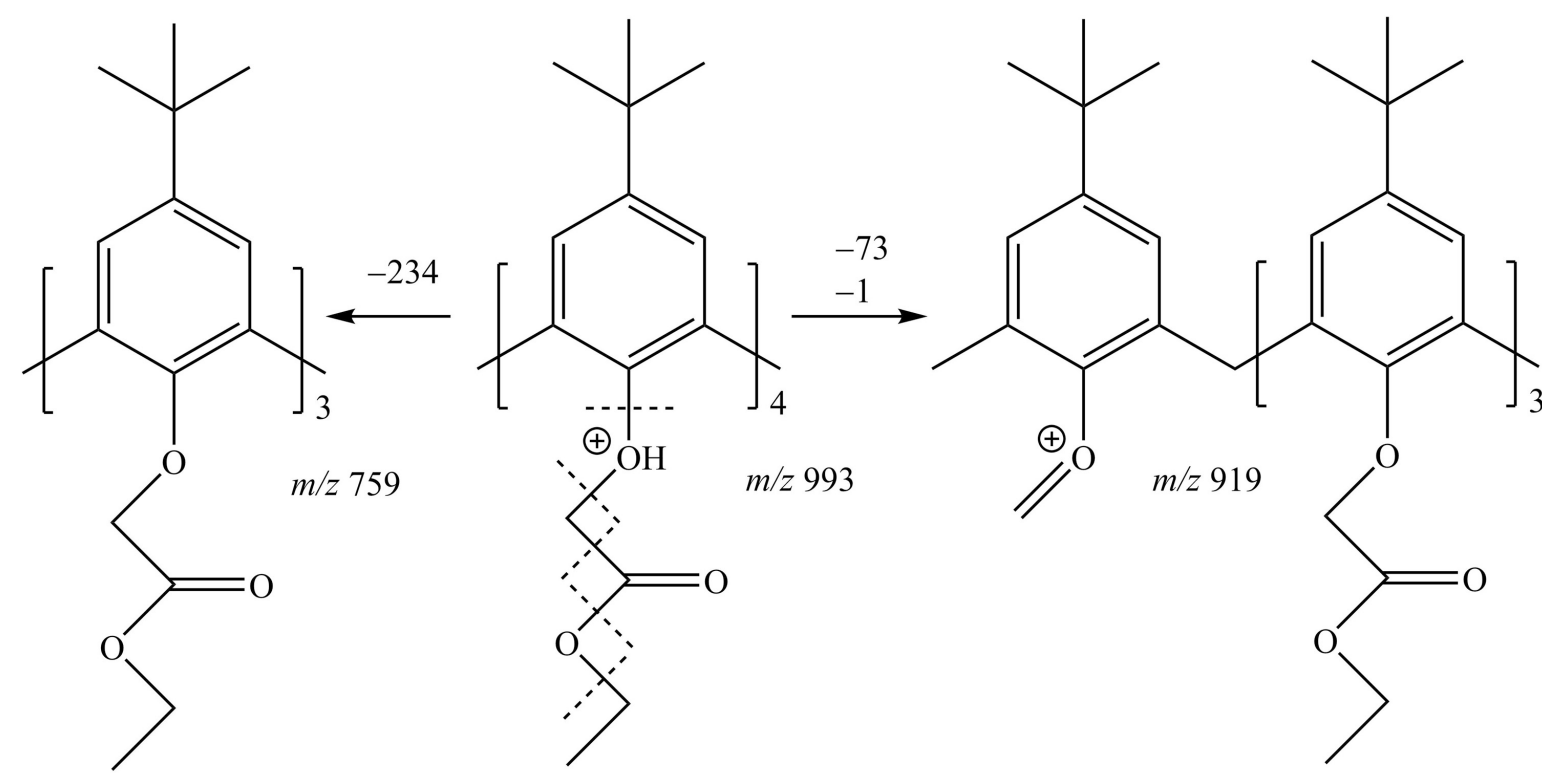<smiles>[Y][13CH][13CH]</smiles><smiles>CCOC(=O)COc1c(C(C)(C)C)cc(C(C)(C)C)cc1C(C)(C)C</smiles><smiles>CCOC(=O)COc1c(Cc2cc(C(C)(C)C)cc(Cc3cc(C)cc(C(C)(C)C)c3)c2OCC(=O)O)cc(C(C)(C)C)cc1C(C)(C)C</smiles>

Scheme 2. Proposed fragmentation pathway of protonated molecule $[1+\mathrm{H}]^{+}(\mathrm{m} / \mathrm{z} 993)$ at $20 \mathrm{eV}$.

resulting in appearance of two new signals in MS/MS spectra, one assigned to the fragment ion $(\mathrm{m} / \mathrm{z} 57)$ and the second one, assigned to the $[2-57+L n]^{2+}$ ion.

However, by applying collision energy of $7 \mathrm{eV}$, the difference in relative stabilities of lanthanide complexes was noticed. As an example, the MS/MS spectrum of $[2+Y b]^{3+}$ is given in Figure 6 .
In the MS/MS spectrum of the less stable complex $\mathrm{La} \cdot \mathbf{2}^{3+}$ the signals corresponding to the cleavage of the calixarene ring and loss of the whole calixarene unit $(-263$

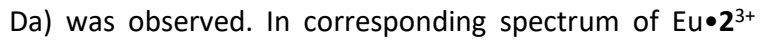
complex, the loss of one subunit $(-101 \mathrm{Da})$ and part of another subunit $(-71 \mathrm{Da})$ was observed. In the MS/MS spectrum of the most stable complex, $\mathrm{Yb} \cdot 2^{3+}$, only the 

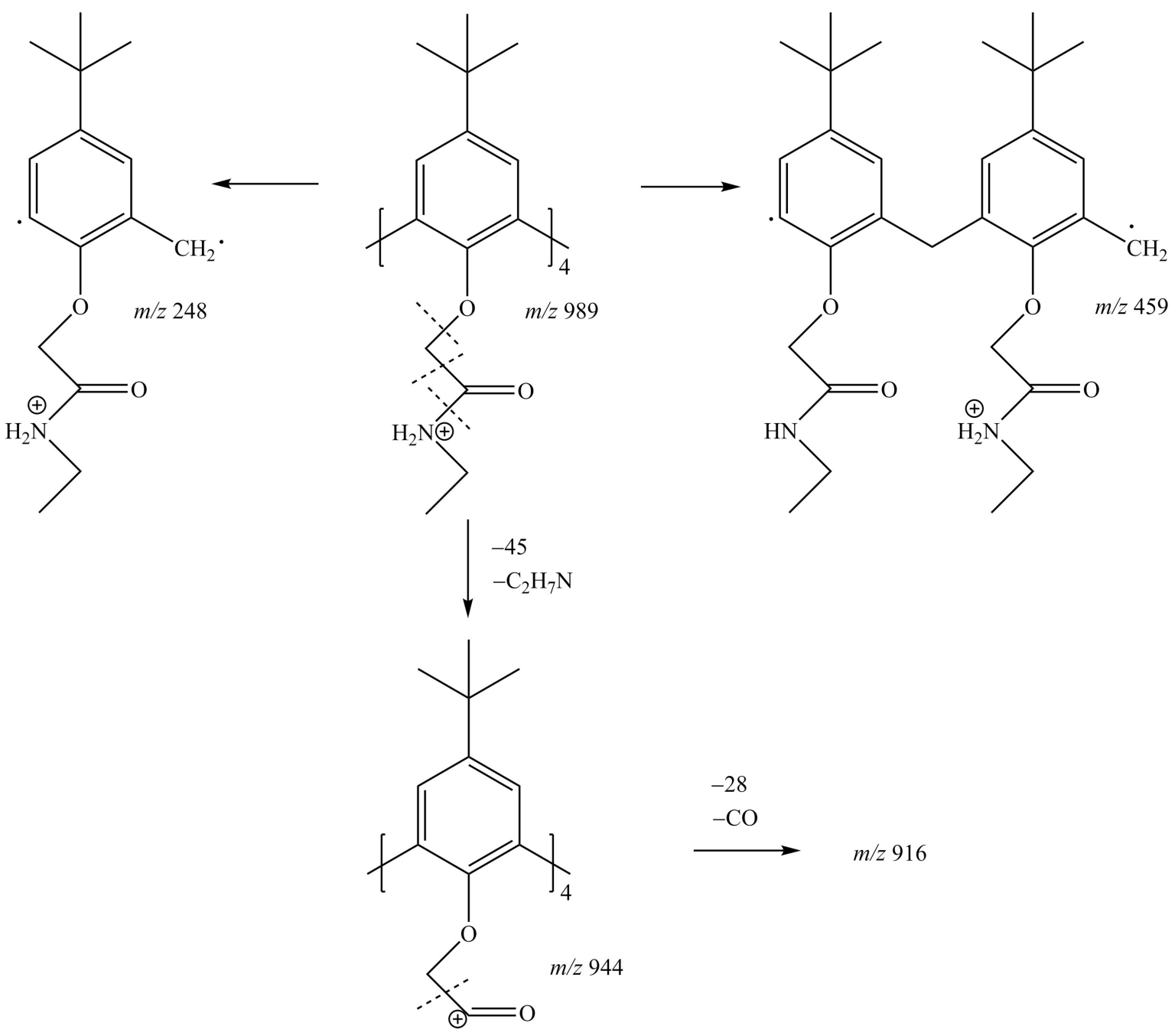

Scheme 3. Proposed fragmentation pathway of protonated molecule $[2+\mathrm{H}]^{+}(\mathrm{m} / \mathrm{z} 993)$ at $40 \mathrm{eV}$.

cleavage of one bond, and the loss of 101 Da were recorded. The same pattern was observed for the fragmentation of $\mathbf{L n} \cdot \mathbf{3}^{3+}$ complexes (Figure S29-S31). However, for the fragmentation of complexes with tertiary-amide, more energy was needed. Even at the collision energy of $20 \mathrm{eV}$, there were still signals of parent ions in the spectrum for complexes with $\mathrm{La}^{3+}$ and $\mathrm{Eu}^{3+}(\sim 15 \%)$. Relative intensity of the signal assigned to $\mathrm{Yb} \cdot 3^{3+}$ complex in MS/MS spectrum amounted to almost $40 \%$ suggesting that the complex with tertiary-amide is the most stable one.

As already mentioned, the most intensive signal in MS spectra of complexes with $\mathbf{2}$ was assigned to the $[2-87+L n]^{2+}$ ion. Beside that signal, the one corresponding to $[\mathbf{2}+\mathrm{Ln}(\mathrm{NO} 3)]^{2+}$ and $[\mathbf{2}-\mathrm{H}+\mathrm{Ln}]^{2+}$ ions were also present. All ions were isolated and fragmented (Figures S32-S39). The loss of $\mathrm{HNO}_{3}(-63 \mathrm{Da})$ and part of subunits were observed in $\mathrm{MS} / \mathrm{MS}$ spectra of $[2+\operatorname{Ln}(\mathrm{NO} 3)]^{2+}$ ions, leading to the
$[2-87+\operatorname{Ln}]^{2+}$ ion. The same ion was also formed by fragmentation of $[2-H+L n]^{2+}$ ions. Additional loss of part and whole subunits was recorded by fragmentation of $[2-87+\mathrm{Ln}]^{2+}$ ion.

In the MS spectra of lanthanide complexes with $\mathbf{3}$, the most intensive signal was assigned to $\left[3+\mathrm{Ln}\left(\mathrm{NO}_{3}\right)\right]^{2+}$ ion, which fragmented by losing $\mathrm{HNO}_{3}(-63 \mathrm{Da})$, and part $(-86 \mathrm{Da})$ or whole subunit $(-100$ or $-116 \mathrm{Da})$ as can be seen from figures $\mathrm{S} 40-\mathrm{S} 42$.

\section{CONCLUSION}

The complexation of selected lanthanide cations $\left(\mathrm{La}^{3+}, \mathrm{Eu}^{3+}\right.$, and $\mathrm{Yb}^{3+}$ ) by calix[4]arene derivatives was studied by spectrophotometric titrations and mass spectrometry. Amide derivatives were more stable in gas phase than the ester derivative. However, by applying enough collision energy, the fragmentation of 


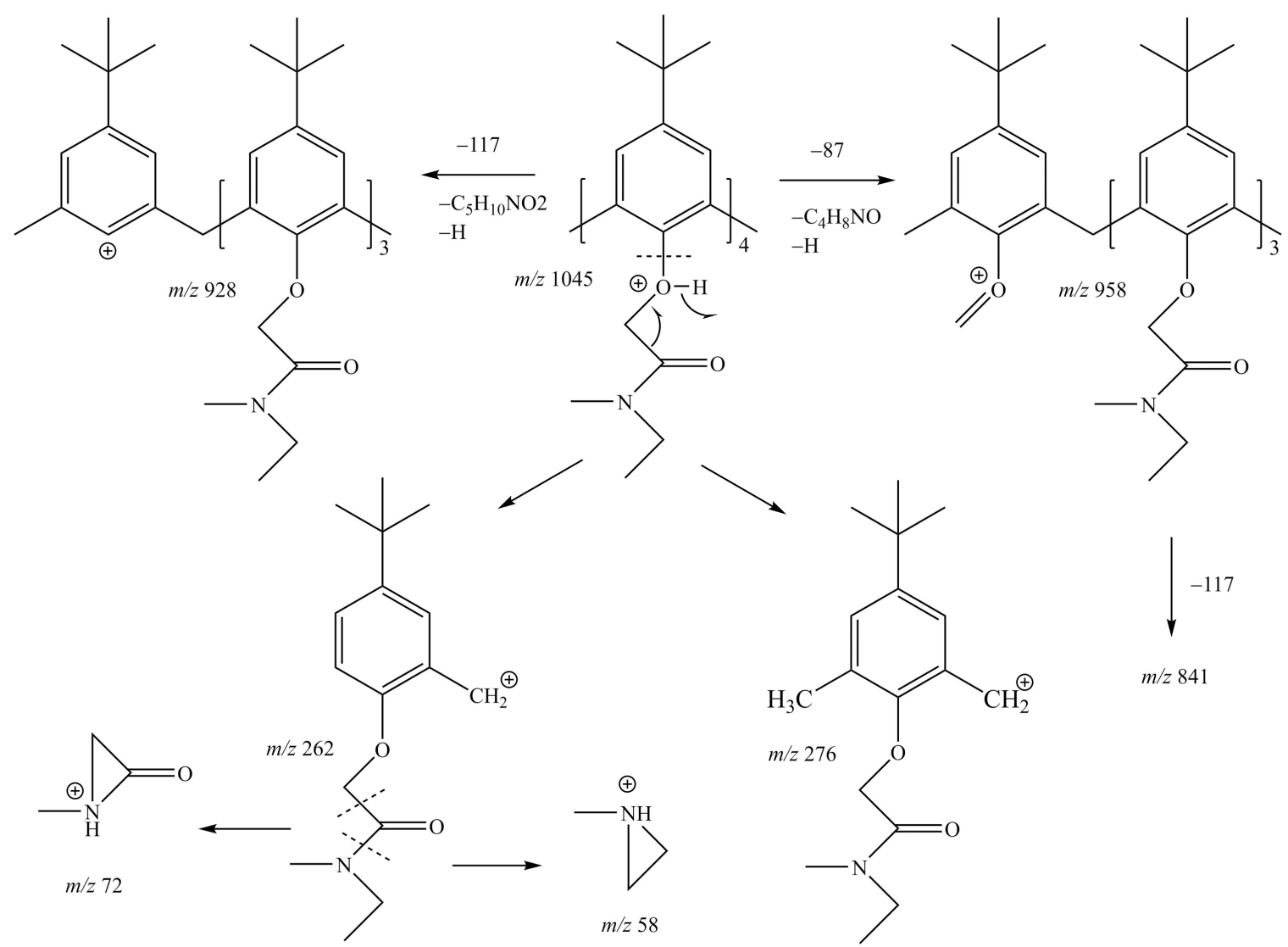

Scheme 4. Proposed fragmentation pathway of protonated molecule $[3+\mathrm{H}]^{+}(\mathrm{m} / \mathrm{z} 1045)$ at $40 \mathrm{eV}$.

whole subunits or its parts, as well as the cleavage of calixarene ring were observed in all cases. The amide derivatives, compound $\mathbf{2}$ and $\mathbf{3}$, efficiently bind lanthanide cations,

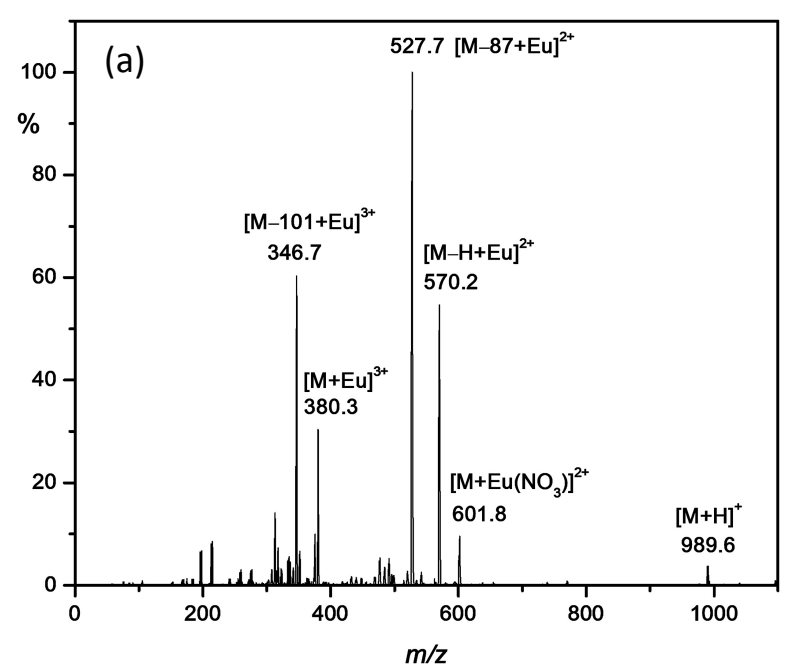

forming $1: 1$ complexes. Based on the results obtained, it can be concluded that amide derivatives are promising extraction agents for lanthanide cations studied in this work.

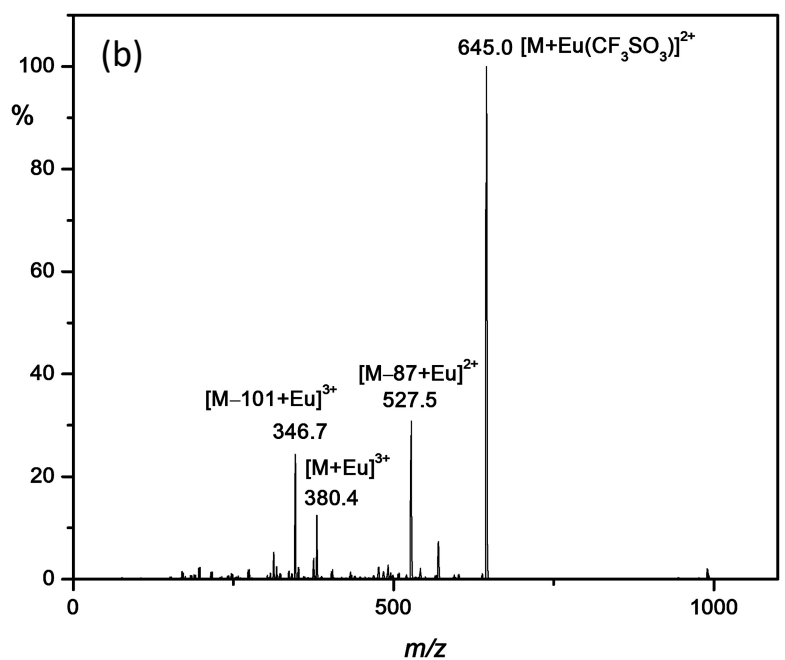

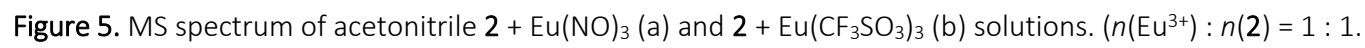




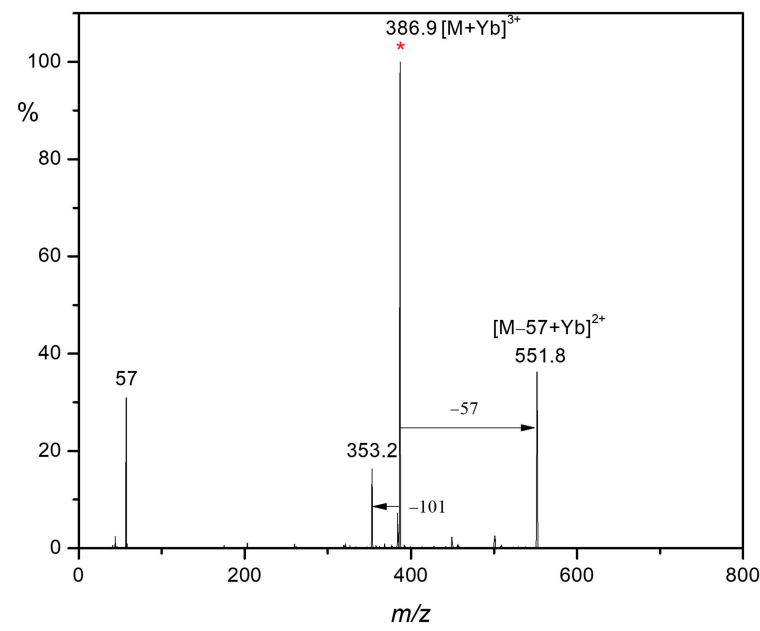

Figure 6. MS/MS spectrum of $[2+\mathrm{Yb}]^{3+}$ at $7 \mathrm{eV}$.

Acknowledgment. This work has been supported by the Croatian Science Foundation (projects: IP-2014-09-4841, IP-2014-09-7309, and IP-11-2013-7387) and by Agencia Nacional de Promoción Científica y Tecnológica (ANPCyT), Argentina, (project: PICT-2014-1997).

Supplementary Information. Supporting information to the paper is attached to the electronic version of the article at: http://doi.org/10.5562/cca3288.

\section{REFERENCES}

[1] M. Atanassova, V. Kurteva, RSC Adv. 2016, 6, 11303.

[2] B. Mokhtari, K. Pourabdollah, N. Dallali, J. Radioanal. Nucl. Chem. 2011, 287, 921.

[3] H. Huang, S. Ding, N. Liu, Y. Wu, D. Su, S. Huang, Sep. Purif. Technol. 2014, 123, 235.

[4] M. Grunder, J. Dozol, Z. Asfari, J. Vicens, J. Radioanal. Nucl. Chem. 1999, 241, 59.

[5] N. Simon, B. Tournois, S. Eymard, G. Volle, P. Rivalier, J. Leybros, J.-Y. Lanoe, N. Reynier-Tronche, G. Ferlay, J.-F. Dozol, Cs Selective Extraction from High Level Liquid Wastes with Crown Calixarenes: Where are we today? http://www.iaea.org/inis/collection/ NCLCollectionStore/_Public/36/010/36010982.pdf

[6] W. Sliwa, T. Girek, J. Incl. Phenom. Macrocycl. Chem. 2010, 66, 15.
[7] B. Mokhtari, K. Pourabdollah, N. Dalali, J. Incl. Phenom. Macrocycl. Chem. 2011, 69, 1.

[8] I. Matulkova, J. Rohovec, Polyhedron 2005, 24, 311.

[9] C. Lamouroux, S. Rateau, C. Moulin, Rapid Commun. Mass Spectrom. 2006, 20, 2041.

[10] M. R. Yaftian, M. R. Razipour, D. J. Matt, Radioanal. Nucl. Chem. 2006, $270,357$.

[11] M. Karavan, F. Arnaud-Neu, V. Hubscher-Bruder, I. Smirnov, V. Kalchenko, J. Incl. Phenom. Macrocycl. Chem. 2010, 66, 113.

[12] M. Mariani, E. Macerata, M. Galletta, A. Buttafava, A. Casnati, R. Ungaro, A. Faucitano, M. Giola, Radiat. Phys. Chem. 2007, 76, 1285.

[13] L. Wang, X. Wang, Y. Wang, Spectrochimica Acta A, 2013, 105, 62.

[14] S. A. Ansari, P. N. Pathak, V. K. Manchanda, M. Husain, A. K. Prasad, V. S. Parmar, Solvent Extr. Ion Exch. 2005, 23, 463.

[15] T. Benković, V. Tomišić, L. Frkanec, N. Galić, Croat. Chem. Acta 2012, 85, 469.

[16] F. Arnaud-Neu, E. M. Collins, M. Deasy, G. Ferguson, S. J. Harris, B. Kaitner, A. J. Lough, M. A. McKervey, E. Marques, J. Am. Chem. Soc., 1989, 111, 8681.

[17] F. Arnaud-Neu, S. Barboso, S. Fanni, M.-J. SchwingWeill, V. McKee, M. A. McKervey, Ind. Eng. Chem. Res. 2000, 39, 3489.

[18] F. Arnaud-Neu, G. Barrett, S. Fanni, D. Marrs, W. McGregor, M. A. McKervey, M.-J. Schwing-Weill, V. Vetrogon, S. Wechsler, J. Chem. Soc. Perkin Trans. 2 1995, 453.

[19] P. Gans, A. Sabatini, A. Vacca, Talanta 1996, 43, 1739.

[20] E. Nomura, M. Takagaki, C. Nakaoka, M. Uchida, H. Taniguchi, J. Org. Chem. 1999, 64, 3151.

[21] L. Frkanec, A. Višnjevac, B. Kojić-Prodić, M. Žinić, Chem. Eur. J. 2000, 6, 442.

[22] V. Tomišić, N. Galić, B. Bertoša, L. Frkanec, V. Simeon, M. Žinić, J. Incl. Phenom. Macro. Chem. 2005, 53, 263.

[23] I. Sviben, N. Galić, V. Tomišić, L. Frkanec, New J. Chem. 2015, 39, 6099.

[24] A. F. Danil de Namor, T. T. Matsufuji-Yasuda, K. Zegarra-Fernandez, O. A. Webb, A. El Gamouz, Croat. Chem. Acta 2013, 86, 1.

[25] K. Leko, N. Bregović, M. Cvetnić, N. Cindro, M. Tranfić Bakić, J. Požar, V. Tomišić, Croat. Chem. Acta 2017, 90, 307. 